\title{
COMUNICAREA VERBALĂ PRIVITĂ DIN PERSPECTIVA ANALIZEI STILISTICE A PREDICII
}

\author{
Florin Mihai ILIESCU*
}

\begin{abstract}
Verbal communication from the perspective of stylistic analysis of the sermon ${ }^{1}$. Communication is the exchange of messages between at least two people, from which one issues (expresses) information and the other receives (understands), provided the partners know the code (know the same language). Communication tool is language. Body language (messa ges transmitted through voice tone, face expression, body position, gestures, etc.) is also an important part of communication. Good communication involves the harmonious combination of verbal language (spoken, written and read) with the nonverbal (expressed by signs, gestures, drawings). The proportions of the communication phenomenon justify the connection between public relations and the Church, as the message of the Gospel is today on the same footing as other types of messages. The premise behind this essay is that the Church can use public relations and it is even recommended to do so in a professional way, but at the same time it must go beyond this level of communication by rewarding the unseen and revelation.
\end{abstract}

Keywords: communication, message, receptivity, sermon, interactions.

\section{Introducere. Predica și elementele care o compun}

Scopul acestui articol rezidă în nevoia de îmbunătăţire stilistică a predicatorului. Comunicarea verbală este un aspect important în toate domeniile vieții, cu atât mai mult pentru slujitorii Bisericii Ortodoxe. Pe baza unei comunicări verbale adecvate se poate ajunge la o comunicare

Priest, PhD Student, Faculty of Orthodox Theology at University from Craiova, Romania.

${ }^{1}$ Studiu realizat sub îndrumarea Arhid. Conf. Univ. Dr. Gelu Călina, care și-a exprimat acordul pentru publicare. 
mai bună între semeni. În acest articol ne-am propus să arătăm că nivelul unei comunicări bune nu este ușor de atins iar slujitorii sfintelor altare trebuie să țină cont de abilitatea transmiterii învățăturilor de credință ortodoxe. Capacitatea de a fi eficient în fața unui auditoriu, vorbindu-le, va determina succesul la care visează orice om. Însă, a expune ideile legate de adevărurile de credință unei persoane sau unei mase de oameni nu implică succesul, ci dorința de a întoarce pe drumul cel drept sufletele rătăcite. O predică eficientă începe printr-o captare a atenției credincioșilor. Predica pe care preotul o ține în fața credincioșilor nu are scopul de a-i manipula. Ea devine cu atât mai importantă cu cât, ,cuvântul e detronat de imagine"2.

Manipularea își propune să convingă oamenii în a demara acțiuni care să producă diverse consecințe în favoarea manipulatorului ${ }^{3}$. În schimb, a persuada, reprezintă capacitatea celui care vorbește de a vorbi din suflet din dorința de a iniţia acțiuni benefice în favoarea propriilor vieți ${ }^{4}$. Pentru realizarea acestui lucru este nevoie ca adevărurile de credință să fie expuse cu stil atât în predica bisericească, dar și în cea particulară.

Pentru ca mesajul evanghelic să fie edificator, predica are nevoie de îndeplinirea mai multor cerințe. Una dintre acestea esteaceea de a fi expusă în spirit biblic și explicată. În felul acesta, oamenii care aud pot înţelege maiușor. Avem înacest sens exemplul parabolei semănătorului, când, după ce a rostit-o, Hristos a explicat-o. $\mathrm{O}$ altă cerință se referă la cel care răspândește mesajul evanghelic. El are datoria de a o face după învățătura ortodoxă. Învățăturile vor fi clare, pentru a nu fi acuzat de răspândirea cunoștințelor eterodoxe. A treia cerință ne trimite la mesajul ce va fi prezentat într-un stil popular, pentru ca ideile să poată fi accesibile și în conformitate cu caracterul și inteligența auditorului. A patra condiție pentru ca o predică să fie reuşită o reprezintă convingerea celui care vorbește ${ }^{5}$.

2 Giovanni SARTORI, Homovidens. Imbecilizarea prin televiziune şi post-gândire, traducere de Iuliana Enache, București, Edit. Humanitas, 2005, p. 11.

${ }^{3}$ Juliet ERICKSON, Arta persuasiunii, traducere de Nicoleta Stroie, Bucureşti, Edit. Curtea Veche, 2013, p. 14.

${ }^{4}$ Andy SzeKely, Comunică, influenţează, convinge, Bucureşti, Edit. As Publishing, 2013, p. 32.

${ }^{5}$ Melchisedec Ştefănescu, Teologia Pastorală, Iași, Edit. Doxologia, 2011, p. 147. 
Stephen Bevans consideră că mesajul evanghelic va avea succes atunci când predicatorii vor transmite cunoștințele într-un mod atractiv, numind procedeul, ,evanghelizare prin atracție"6.

Stilul de a comunica se exprimă şi prin predică. Chiar dacă mesajul religios sau duhovnicesc trebuie adus în actualitate, nu trebuie adus întrun caracter fals, ci în duhul evanghelic. Acest mod de exprimare siropos, de impresionare sau bombastic, specific protestanților, dar fără bază a adevărului, se numește schimosire sau schimonosire, adică stricare sau abatere de la adevărul Bisericii ${ }^{7}$.

Graiul pe care predicatorul îl folosește în procesul evanghelizării trebuie să fie pe înțelesul tuturor oamenilor care ascultă. Nu trebuie pierdut din vedere stilul cultivat pe care-1 va expune. Va fi atent atât la modul gramatical de exprimare, cât și la logica ideilor. Acestea vor avea o continuitate. Predicatorul nu va uita că învățătura pe care o exprimă în mod logic trebuie să ajungă la sufletele oamenilor care ascultă. În timpul predicii, dacă exprimarea este logică, toate cunoștințele și învățăturile pe care le exprimă vor fi exacte. Înlănţuirea lor rațională ajută la expunerea ideilor. Șirul ideilor nu se pierde.

\section{Gesturile și ținuta predicatorului}

Modul în care ne purtăm și maniera în care gesticulăm în fața auditoriului determină reușita. Cuvintele rostite pot fi deosebite și bine așezate în pagină, putând avea continuitate. Însă, dacă detaliile sunt ignorate, predica nu reuşește ${ }^{8}$.

Când se rostește o predică, cel care vorbește va avea în colțul gurii, pentru fiecare om care a venit să-l asculte, un zâmbet. Dar nu întotdeauna, ci doar când situațiile o cer. Este inutil pentru un predicator să rostească tot felul de cuvinte optimiste, dar el să fie încruntat. Printr-un zâmbet se intră în contact vizual cu auditoriul. Procedând astfel, creștinii veniți întâmplător sau nu la biserică îl vor întâmpina pe predicator cu multă căldură.

${ }^{6}$ Stephen B. Bevans, Pregustând Impărăția lui Dumnezeu, traducere de Emil M. Mărginean și Alexandru Buda, Cluj-Napoca, Edit. Presa Universitară Clujeană, 2019, p. 177.

${ }^{7}$ Melchisedec ŞTEFănescu, Teologia Pastorală, p. 148.

${ }^{8}$ Savatie Baștovor, Când pietrele vorbesc. Mic tratat despre predică, Bucureşti, Edit. Cathisma, 2010, p. 47. 
Ținuta lui, plecând de la modul îngrijit și adecvat până la gestică, este foarte importantă, întrucât oamenii ne văd și abia mai apoi ne aud. Când ne hotărâm să servim un fel de mâncare, ne atrage mai întâi mirosul, iar într-un final apreciem sau dezapreciem gustul ${ }^{9}$. Mirosul îmbietor atrage clienții. Pentru ca auditoriul să fie stimulat pentru a fi atent și atras de predica pe care unmisionar sau preot oține, mai întâi trebuie el trebuie să stârnească interes printr-o îmbrăcăminte adecvată, prin mimica feței, prin gesturi și modul cum folosește mâinile. Comportamentul elegant și ținuta îngrijită transformă un predicatorîntr-un vorbitor de succes. Aceste aspecte sprijină mesajul pe care îl transmite.

Mișcările membrelor corpului făcute în exces pot să-i facă pe oameni să fie mai atenți la acestea decât la mesajul pe care îl transmite. Repetarea lor în continuu distrage atenția. În schimb, dacă gesticulațiile sunt făcute cât mai rar și cu un scop anume, ele își ating ținta ${ }^{10}$.

Mâinile nu se vor duce niciodată la spate în timp ce se ține o predică. Acest gest transmite un mesaj distrugător pentru credincioșii care ascultă ${ }^{11}$. Preotul lasă impresia că ar ascunde ceva și pare a nu fi corect față de auditoriu. Cel mai indicat ar fi ca mâinile să fie ținute pe lângă corp, iar, dacă sunt ridicate, nu se va face acest gest mai mult de nivelul gâtului ${ }^{12}$. Mișcările, dacă sunt făcute rar și largi, transmit oamenilor mesajul că cel care vorbește stăpânește emoțiile ${ }^{13}$. Când degetele mâinii cu care gesticulează sunt lipite, acest lucru transmite mesajul potrivit căruia predicatorul este un om ce inspiră autoritate. Degetele răsfirate, în timpul unui cuvânt, reprezintă un dezavantaj pentru preotul care vorbește, fiindcă transmit nesiguranță. Brațele nu vor sta niciodată încrucișate atunci când se ține un discurs în public, întrucât acest gest pune o barieră între credincioși și preot.

Când se comunică unui public larg o învățătură de credință sau un mesaj printr-un purtător de cuvânt, umerii vor fi drepți, iar capul va fi ținut sus ${ }^{14}$. Aceasta face ca ideile să fie transmise eficient. Această poziție

9 Kevin Hogan, Psihologia persuasiunii, traducere de Alexandru Florescu, București, Edit. Antet Press, 1996, p. 34.

${ }_{10}^{10}$ Andy SzeKely, Comunică, influenţează, convinge, p. 52.

${ }^{11}$ Juliet ERICKSON, Arta persuasiunii, p. 16.

${ }^{12}$ Giovanni SARTORI, Homovidens. Imbecilizarea prin televiziune şi post-gândire, p. 15.

${ }^{13}$ Kevin Hogan, Psihologia persuasiunii, p. 54.

14 Zig Ziglar, Pe culmile succesului, traducere de Nicoleta Griciuc, București, Edit. Amaltea, 2000, p. 59. 
pe care predicatorul o ia arată putere și încredere în mesajele pe care le transmite. Poziția cocoșată nu-l avantajează pe vorbitor, deoarece mâinile nu pot fi controlate decât din coate. ,Mâinile sunt definite în oratorie ca fiind semnele de puctuație și de exclamare ale corpului" ${ }^{15}$.

În timp ce predicatorul ține un cuvânt de învățătură, nu este indicat a se juca vreodată cu hainele preoțești sau cu mâneca de la reverendă. Bătutul cu degetul în masă ori în sfânta cruce, în timp ce o ține cuprinsă între cele două mâini, vor distrage atenția oamenilor veniți să asculte sfaturi duhovnicești. Creștinii nu pot să ignore un obiect care se găsește în mișcare ${ }^{16}$.

Aflându-se pe amvon în calitate de preot, acesta, după ce s-a ridicat de pe scaun și s-a amplasat în faţa oamenilor, nu le va vorbi imediat. Mai întâi, își va privi auditoriul, va respira adânc și câteva clipe va pune tăcere. Acest lucru ajută să dispară gălăgia din biserică, iar oamenii să fie atenți.

\section{Vocea - aliatul unui predicator}

Atunci când un preot ține o predică în fața unui auditoriu de calitate, vocea îi este afectată de emoții. Gâtul și limba se încordează, iar vocea devine țipătoare din dorința de a fi auzit de toți și a face o impresie bună.

Pentru o reușită elocventă, predicatorul trebuie să-și controleze respiratia. Dacărăspundenecontrolat, în interiorul său vor exista tensiuni. Există riscul ca în timpul vorbirii cutia toracică să se înguste ${ }^{17}$. Pentru a ne face înțeleși, dăm exemplul balonului care este umflat și strâns la capăt în așa fel încât cantitatea de aer să iasă treptat ${ }^{18}$.

Pentru ca în voce să nu se simtă emoțiile, cel care vorbește în public se va obișnui să respire din diafragmă. ,Diafragma este un mușchi subțire care se află la baza plămânilor, deasupra cavității abdominale"19. Dacă

\footnotetext{
${ }^{15}$ Idem, Motive pentru a zâmbi, traducere de Nicoleta Griciuc, București, Edit. Curtea Veche, 2013, p. 43.

${ }^{16}$ Larry KING, Secretele comunicării, traducere de Manuela Iris, București, Edit. Amaltea, 2000, p. 62.

${ }^{17}$ Padron Paciano, Cum vorbim în public, traducere de Violeta Limona, Bucureşti, Edit. Universitară, 2012, p. 44.

${ }^{18}$ Ibidem, p. 45.

${ }^{19}$ Ibidem, p. 46.
} 
respirația care influențează vocea este controlată, aceasta nu trădează sentimentele pe care le are predicatorul. Stăpânind exercițiile pentru respirația pe diafragmă, vocea poate fi clară, tare și timbrul ferm. Dacă fermitatea se simte în glas, acest aspect îi face pe credincioşi să dea importanță cuvintelor spuse de el și să fie atenţi.

De asemenea, vocea va transmite sinceritate și va reuşi să fie utilizată cu inflexiuni. Cuvintele vor fi scoase prin cavitatea bucală cu claritate și acuratețe.

În timpul unei cuvântări, ritmul cuvintelor rostite nu va fi exprimat într-un mod alert. Este bun dinamismul impus unui discurs, dar nu se va da publicului un ritm prin care nu reușește să înțeleagă toate ideile primite. Ideile celui care vorbește vor trebui să fie procesate de oamenii care ascultă. Altfel, aceștia nici nu pot reflecta la cuvintele pe care le-a rostit predicatorul. Ritmul controlat al acestuia îi permite să-și clădească un stil de succes predicatorial.

Când emoțiile copleșesc vocea celui care vorbește, acesta trebuie să se gândească la discuțiile relaxante pe care le avea cu prietenii. În acele circumstanțe se folosește o voce fïrească și naturală, pentru că mușchii specifici vorbitului nu sunt încordaţi ${ }^{20}$.

Pentru ca vocea să fie aliatul predicatorului, ea mai trebuie încălzită. Pentru aceasta există o serie de exerciţii de respirație ce se recomandă pentru ca preotul care convertește să-și etaleze o voce puternică și penetrantă. Un exercițiu folosit de foarte mulți vorbitori profesioniști este inspiratul încet pe nas, numărând până la zece, după care urmează expiratul pe gură, respectând tot același timp ${ }^{21}$. Iată că, prin acest gen de exerciții, se încearcă depozitarea unei cantități cât mai mare de aer care să ajute la terminarea fiecărei propoziții în parte. Aceste respirații controlate ajută vocea să câștige volum și să emită căldură. Pentru ca vocea, în timpul vorbirii în public, să prindă contur și să fie puternică, este nevoie de exercițiu. Prin el, glasul poate căpăta volum și forță.

Entuziasmul pe care-1 emite vocea, intonația și modul cum se ondulează sunetele vocii pot fi comparate cu un tablou ce prezintă un

${ }^{20}$ Dale CARnEgIE, Cum să vorbim în public, traducere de Anghel Gâtlan, Bucureşti, Edit. Curtea Veche, 2008, p. 39.

${ }^{21}$ Ibidem, p. 41. 
peisaj pictat în multe culori vii. Intonația care nu există în timpul unei prezentări a învățăturii de credință poate fi comparată cu un tablou colorat în nuanțe gri. Şi aici formele apar, dar lipsesc culorile.

Pentru ca vocea să aibă putere, spre a fi auzită până în spatele sălii sau al bisericii, este recomandat ca toate cuvântările să fie rostite rar. În felul acesta ascultătorii pot absorbi liniștiți și pot înțelege mesajul.

Dar forța unei predici nu o dă doar vocea puternică, ci și pauzele. Acestea trebuiesc făcute între idei. După ce fiecare idee a fost dezvoltată, vorbitorul va face o pauză. În felul acesta, oamenii care ascultă conștientizează că se trece la o altă idee ${ }^{22}$.

Pauzele din timpul vorbirii sunt de mai multe feluri. Prima dintre ele se folosește când o propoziţie se termină pentru ca auditoriul să o poată înțelege. Cea de-a doua pauză mai este numită și dramatică și este folosită când predicatorul și-a propus ca ideea să rămână întipărită în mințile oamenilor care ascultă ${ }^{23}$. A treia pauză se mai numește și autoritară, ea impunându-se atunci când este gălăgie în sala unde se vorbește sau în biserică, iar predicatorul încearcă să instaureze liniștea. Ultima, și anume pauza pentru completarea frazei, se utilizează după ce predicatorul a rostit un citat din Sfinții Părinți ori un aforism, pentru ca audiența să devină interesată ${ }^{24}$.

\section{Modul de comunicare și procedeele retorice}

Pentru a comunica eficient nu trebuie mers la o prezentare de predică fără o pregătire prealabilă. Există riscul ca majoritatea credincioșilor să respingă mesajele pe care preotul le transmite. Mai mult, dacă ceea ce rostește nu este util pentru oameni, aceștia nu devin interesați. Ei trebuie captați prin idei care-i interesează. Vorbele nu sunt aruncate în aer oricum ar fi, ci sunt așezate în idei succesive și logice.

Când se începe o cuvântare, necesar ar fi ca predicatorul să aibă un obiectiv pe caresă și-l propună înainte de predică. El trebuie să-și propună

22 Dale CARnegie, Liderul poţi fi tu, traducere de Anghel Gâtlan, Bucureşti, Edit. Curtea Veche, 2011, p. 54.

${ }^{23}$ Silvia SăVUlESCU, Retorica şi teoria argumentării, Bucureşti, Edit. Univers, 2001, p. 65.

${ }^{24}$ Ibidem, p. 66. 
un scop ce poate fi realizabil. Începând de la introducere și terminând cu încheierea, predica va trebui să-și îndeplinească dezideratul propus.

Dacă o predică a fost ținută cu stil, credincioșii își vor aduce aminte întotdeauna de ea. Sunt multe cazuri de predici care se rostesc și sunt uitate la câteva ore după terminarea lor. Nu transmit niciun mesaj, iar oamenii nu au avut de ce să le țină minte. Atenția pusă pe accentul unui cuvânt sau alunei expresii ajută predicatorul să rostească o cuvântareîntrun mod muzical. Atenția auditoriului va putea fi captată, iar preotul va fi privit ca un orator stilat.

Pentru un mod de comunicare cu stil al mesajului evanghelic devine necesară măsura preotului de a studia oratorii buni care au succes sau teologii care umplu sălile atunci când țin conferințe.

Apoi, nu trebuie uitat nici cititul foarte mult şi des al predicatorului. Studiul îl ajută a avea cunoștințe vaste și a le stăpâni. Atunci când va găsi un neologism ori un arhaism, va cerceta și va lua din dicționare alte câteva sinonime. Motivul este următorul: Când auditoriul aude explicaţi termeni neutilizați într-un mod simplu, li se transmite încrederea că preotul știe ce spune, adică este bine informat. In caz contrar, credibilitatea predicii respective scade, iar oamenii nu mai sunt influențați în mod emoțional ${ }^{25}$. Nu este exclus ca în sala unde se predică sau în locaşul de cult să existe oameni cu studii superioare ce ar aprecia gradul de cultură al preotului, fapt care i-ar atrage spre participarea la viitoarele slujbe.

Predicatorul nu se va gândi la oamenii care-1 ascultă ca la o adunătură amorfă de cetățeni veniți în trecere prin biserică. Ori, o comunicare eficientă și cu stil se poate realiza atunci când acei oameni sunt priviți ca un tot unitar, ca o singură persoană. Când a început să vorbească, gândul nu va mai fi ațintit către sine, ci către fiecare om în parte. Comunicarea va deveni mai uşoară.

Dacă predicatorul va cunoaște obiceiurile locului, poate să se refere și la acestea. Cunoscând oamenii prin intermediul regiunii în care locuiesc, se va face înțeles mai bine și va deveni convingător ${ }^{26}$. Aceste afirmații sunt întărite de atitudinea Mântuitorului nostru Iisus Hristos. El,

${ }^{25}$ Bryan TRACY, Secretele puterii de convingere, traducere de Violeta Limona, București, Edit. BusinessTech, 2013, p. 24.

${ }^{26}$ Dale CARnegIe, Cum să vorbim în public, p. 60. 
când îi învață pe oameni, Se folosea de parabole. Făcea legătura cu locurile de muncă pe care le aveau oamenii din regiunea respectivă ${ }^{27}$. Un exemplu elocvent este chiar parabola semănătorului, când, știind că oamenii din acea zonă se îndeletniceau cu agricultura, le-a vorbit despre un semănător care a aruncat felurite semințe pe ogorul său.

Nici nu trebuie exagerat în explicarea unor amănunte legate de un subiect. A se pierdeîn tot felul de detalii îi limitează oratorului capacitatea de a se referi la esențial. Ceea ce este important îi va ajuta pe oameni să țină minte mai ușor. Lucrurile exagerate plictisesc.

Una din metodele de comunicare moderne se numește ,,ștergătorul de parbrize" 28 . Ea se referă la ideile care sunt expuse și susținute de povestioare atractive și pline de învățături duhovnicești. Atunci când va veni o altă idee, ea va fi susținută de un citat celebru. Ideea care va urma, va fi ancorată într-o ilustrare numerică ${ }^{29}$.

$\mathrm{Ca}$ procedeu retoric nu va fi trecută cu vederea nici metoda analogică $\breve{~}^{30}$. Ea se referă la puterea predicatorului de a explica o idee încercând să o compare cu altceva. Prin această metodă, ceea ce pare complicat va deveni foarte clar. O exemplificare prin care ne putem face înțeleși este comparația găsită în Sfânta Scriptură, când Iisus era batjocorit de romani atât de cumplit încât și cerul se întunecase ${ }^{31}$.

Un alt procedeu care poate trezi interesul auditoriului prin rimele pe care le creează este aliterația ${ }^{32}$. Aceasta constă din reiterarea unui segment de text aşezat la începutul unei propoziții sau sintagme de cuvânt: „Ești cult și te ascult" sau: "Propun dar nu impun” 33 . Astfel de artificii oratorice îmbogățesc o predică și-i acordă melodicitate.

$\mathrm{O}$ altă figură de stil oratorică ce poate face completă o predică se numește ,,catahreza”, cuvânt ce provine din limba greacă - katahrisis-

${ }^{27}$ Ibidem, p. 61.

${ }^{28}$ Silvia SăVULESCU, Retorica şi teoria argumentării, p. 49.

${ }^{29}$ Ibidem, p. 50.

${ }^{30}$ Dale CARnEGIE, Liderul poţi fi tu, p. 61.

${ }^{31}$ Padron PaCiano, Cum vorbim in public, p. 10.

${ }^{32}$ Paul ToIT, Secretul prezentărilor de succes, traducere de Paul Mihalache, Bucureşti, Edit. Curtea Veche, 2012, p. 70.

33 John Maxwell, Cum să devii popular, traducere de Manuela Iris, Bucureşti, Edit. Curtea Veche, 2007, p. 30. 
și înseamnă folosirea improprie a unui cuvânt ${ }^{34}$. Această figură se folosește atunci când predicatorul nu găsește un corespondent potrivit pentru ceea ce dorește să spună. Când limba română nu are un cuvânt propriu pentru un lucru, se apelează la această tehnică oratorică. Pentru a ne face înțeleși, am găsit în Sfânta Scriptură un text care scoate în evidență, prin exemplificare, ce am expus anterior: „Atunci diavolul La dus în sfânta cetate și L-a pus pe aripile templului” (Mt. 4, 5).

$\mathrm{Nu}$ trebuie să uităm nici artificiul oratoric numit repetiția ${ }^{35}$. Prin repetarea unui cuvânt sau a unui grup de cuvinte rostite, se atrage atenția celor care ascultă. În timpul unei predici, oamenii nu sunt atenți în totalitate la ideile expuse de preot. Pentru a-i face atenți, dar și pentru a întări o idee pe care dorește să o exprime, preotul poate apela la aceasta. Un exemplu elocvent în acest sens îl regăsim în Sfânta Scriptură, atunci când Sfântul Apostol Pavel le scrie o epistolă corintenilor: ,În călătorii adesea, în primejdii de râuri, în primejdii de la tâlhari, în primejdii de la neamul meu, în primejdii de la păgâni, în primejdii de la cetăți, în primejdii în pustiu, în primejdii pe mare, în primejdii între fraţii cei mincinoși”"(II Cor. 11, 26).

\section{Concluzii}

Predica este extrem de importantă, întrucât omul a devenit captiv civilizației contemporane, care preferă vizualul sub argumentul că imaginea exprimă adevărul. Pentru că ne găsim în era videocrației, unde imaginea are un rol deosebit în implementarea de idei, cuvântul exprimat prin predică va căpăta importanță. Imaginile vizuale fac să se piardă din conținutul unui adevăr care se vrea comunicat. Informarea vine prin simțul văzului, fără să ne dăm seama că imaginea o poate duce în eroare. De aceea, printr-o predică stilizată, civilizația vizualului poate prinde consistență.

Cuvântul predicatorului ex primat într-un fel rafinat și expus întrun mod elocvent creează valoare conținutului religios. Predica ținută de pe amvon sau în particular nu este ținută pentru ca cel care o împlinește

\footnotetext{
${ }^{34}$ Vasile Gordon, Adrian Ivan, Nicuşor Beldiman, Omiletica, București, Edit. Basilica, 2015 , p. 472.

35 Ibidem, p. 474.
} 
să fie omagiat sau apreciat, ci ca să-l ajute pe ascultător a trăi prezența lui Dumnezeu, schimbându-și astfel viața. Așadar, mesajul evanghelic transmis cu stil îi va face pe oamenii care l-au ascultat să-şi aducă întotdeauna aminte de învățăturile auzite.

\section{Referinţe bibliografice:}

1. BaștovoI, Savatie, Pietrele vorbesc, mic tratat despre predică, Bucureşti, Edit. Cathisma, 2010;

2. Bevans, B. Stephen, Pregustând Împărăția lui Dumnezeu, traducere de Emil M. Mărginean și Alexandru Buda, Cluj-Napoca, Edit. Presa Universita ră Clujeană, 2019;

3. CARNEGIE, Dale, Cum să vorbim în public, traducere de Anghel Gâtlan, Bucureşti, Edit. Curtea Veche, 2008;

4. CARNEGIE, Dale, Liderul poțifi tu, tra ducere de Anghel Gâtlan, Bucureşti, Edit. Curtea Veche, 2011;

5. ERICKSON, Juliet, Arta persuasiunii, traducere de Nicoleta Stroie, Bucureşti, Edit. Curtea Veche, 2013;

6. GORDON, Vasile, IVAN, Adrian, BELDIMAN, Nicușor, Omiletica, București, Edit. Basilica, 2015;

7. Hogan, Kevin, Psihologia persuasiunii, traducere de Alexandru Florescu, București, Edit. Antet Press, 1996;

8. KING, Larry, Secretele comunicării, traducere de Manuela Iris, București, Edit. Amaltea, 2000;

9. MAXWELL, John, Cum să devii popular, traducere de Manuela Iris, Bucureşti, Edit. Curtea Veche, 2007;

10. PACIANO, Padron, Cum vorbim în public, traducere de Violeta Limona, Bucureşti, Edit. Universita ră, 2012;

11. SARTORI, Giovanni, Homovidens. Imbecilizarea prin televiziune și postgândire, tra ducere de Iuliana Enache, București, Edit. Humanitas, 2005;

12. SĂVULESCU, Silvia, Retorica şi teoria argumentării, Bucureşti, Edit. Univers, 2001;

13. SZEKELY, Andy, Comunică, influenţează, convinge, Bucureşti, Edit. As Publishing, 2013;

14. ŞTEFĂNESCU, Melchisedec, Teologia Pastorală, Iași, Edit. Doxologia, 2011 , 
15. TOIT, Paul, Secretul prezentărilor de succes, traducere de Paul Mihalache, Bucureşti, Edit. Curtea Veche, 2012;

16. TRACY, Brian, Secretele puterii de convingere, traducere de Violeta Limona, București, Edit. BusinessTech, 2013;

17.ZIGLAR, Zig, Motive pentru a zâmbi, traducere de Nicoleta Griciuc, București, Edit. Curtea Veche, 2013;

18.ZIGLAR, Zig, Pe culmile succesului, traducere de Nicoleta Griciuc, București, Edit. Amaltea, 2000. 